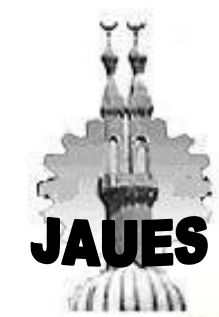

Journal of Al-Azhar University Engineering Sector

Vol.16, No. 61, October, 2021,1171-1183

\title{
STUDENTS ENGAGEMENT IN E-LEARNING ENVIRONMENTS- A COMPREHENSIVE MODEL: MEASUREMENT, EVALUATION, AND RECOMMENDATIONS
}

\author{
Ahmed Asmat Mahmoud ${ }^{1}$, Shehab Gamal el-Din ${ }^{1}$, Gamal Tharwat ${ }^{1}$ \\ ${ }^{1}$ Systems and Computers Engineering Department, Faculty of Engineering, Al-Azhar University, Cairo, Egypt. \\ *Corresponding Author E-mail: Eng.asmat@gmail.com
}

ABSTRACT

Online learning has become at the core of education systems, especially after the Corona pandemic. Noteworthy, LMS (Learning Management System) records all students' actions, which is difficult in traditional education systems, which, if properly analyzed, can give a clear picture of the student's learning behavior.

This study focuses on measuring and analyzing students' engagement with courses, thus providing students, teachers, and academic advisors with recommendations for improvement. Research has shown that the more students' engagement the higher the success rate. Therefore, we consider high engagement as a key success indicator in an education system.

This research identified the system-interaction attributes influencing the student's engagement with a course. It integrates those attributes into a model for measuring and evaluating the degree of student's engagement - the LAST-CASE Model. The LAST-CASE model is designed to measure the different engagement dimensions, such as cognitive, social, academic, and affective dimensions as recommended by the Community of Inquiry (CoI). This article describes how to measure such attributes using both the LMS log and the xAPI method. In addition, we shed lights on how to assess the degree of "engagement" on different themes, e.g., for a student in a course, for a student across all courses in a particular field, for different students in different classes for the same course but taught by different teachers, etc.

Keywords: Student' engagement; learning management system; theoretical framework; Adaptive eLearning; recommendations; learning analytics; learner model.

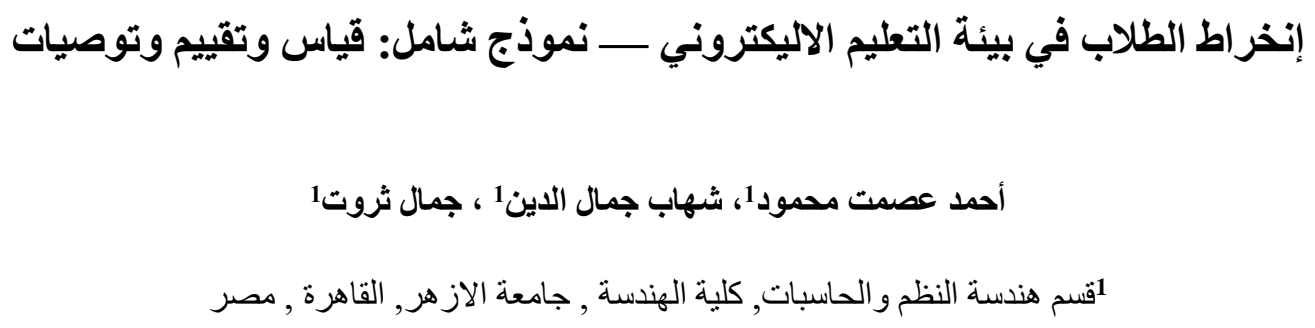

E-mail Eng.asmat@gmail.com البريد الاليكتروني اللباحث الرئيسى:* 


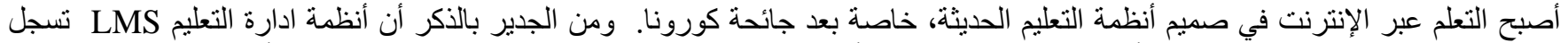
جميع تفاعلات الطلاب مع النظام، و هو أمر لا يمكن القيام به في الأنظمة التقليدية، والذي إذا تم تحليله بشكل صحيح، يمكن أن يعطي صورة واضئ واضحة عن السلوك التعلمي للطاعلب.

هذا البحث، يركز على قياس وتحليل درجة "انخر اط" الطالب (student engagement) في المقررات التي يدرسها، وبالتالي تقديم نصائح

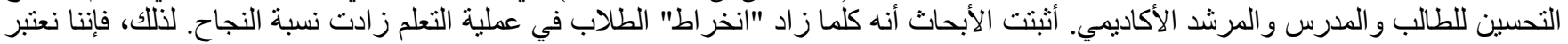
"الانخر اط" مؤشر نجاح رئيسي لنظام التعليم.

حدد هذا البحث مجموعة من مؤشرات التفاعل مع النظام المؤثرة في انخر اط الطالب مع المقرر. . ولقياس وتقيبم درجة "انخر اط الطالب تم التكامل

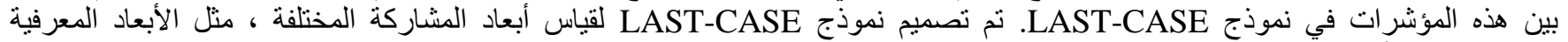

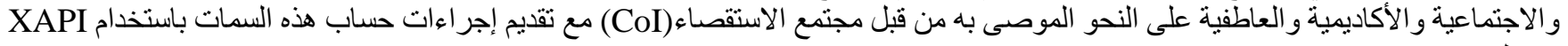
وسجلون.LMS.

بالإضافة إلى ذلك، تلقي هذه المقالة الضوء أيضًا على كيفية تقييم درجة "الانخر اط" على محاور عدة، أفقيا ور أسيا؛ فعلى سبيل المثال، لطالب في

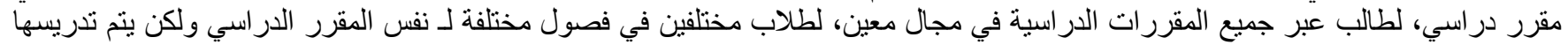

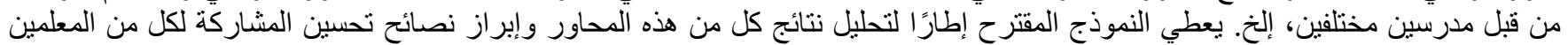
و الطلاب و المرشدين الأكاديمبين.

الكلمات المفتاحية : التعليم الالكتروني ,انخر اط الطالب , نظام ادارة التعليم , التعليم الالكترونسي التكيفي , توصـيات و تحليلات التعلم , ونمـوذج

\section{INTRODUCTION}

e-Learning has become a fundamental element in the educational process [1], especially after the Corona pandemic. However, the activation of e-Learning expectedly encountered the traditional resistance to change. High student engagement is a key performance indicator (KPI) for the success of any education system, especially e-Learning. In fact, engagement is defined as the commitment or involvement [2], therefore, student engagement is a key indicator of the success or failure of a course or an education system [3]. Therefore, it has recently received special attention from researchers in e-Learning [3], [4], [5].

However, the measurement of students' engagements requires a large data set, a tough thing to obtain [6]. This research used a published Moodle dataset [20]. Noteworthy, a tremendous effort was excerpted in preprocessing and preparing this published data to become suitable for automated analytical manipulation; an effort that is considered outside the scope of this article.

On another dimension, Experience Application Programming Interface (xAPI) [7] is a specification for multienvironment e-learning technology that makes it possible to collect data about a wide range of experiences a learner has. This API gathers data in a consistent format about the activities of a learner from different environments and stores it in a Learning Record Store (LRS).

Therefore, this research used both the log data of an LMS (Moodle) and the data collected by a XAPI's LRS to stand on all activities and interactions of the student with a course and its related contents to measure his/her engagement level.

In this article, proposes a framework for student engagement, which, is composed of two main models: The Cognitive-Academic-Social-Emotional model (CASE) and the Level-academic-challenge, Active-collaborativelearning, Student-learning experience environment interaction, and Time-spent on task (LAST) model. As indicated by their names, both of the two models focus on measuring the student engagement from different perspectives leading to building a comprehensive collaborative image of the strengths and weaknesses of the relationship between the student and the course. The analysis of the achieved results of the LAST-CASE model enables offering automated advices to all of the involved stakeholders, e.g., students to improve their engagement and hence their outcomes, course authors/instructors to enhance their design of the course; teachers to improve their teaching strategy, and education administrators/supervisors to assess and revise the course objectives. 
Lots of key performance indicators (KPIs) can be obtained from the LAST-CASE model, however, this article focuses only on those that are highly recommended by the Community of Inquiry (CoI) [8].

In fact, we are not aware of any prior studies that have a comprehensive engagement model as the LAST-CASE model. In addition, almost no prior researches that employed students' engagement measures to provide educational improvement recommendations [9].

The rest of this paper is structured as follows. Section 2 reviews some related published work, while Section 3 describes the proposed student engagement framework after reviewing the different dimensions considered in this framework. Section 4 suggests the different measurement supporting the framework, while Section 5 sheds lights on the implementation the proposed model for Moodle platforms. Section 6 concludes and highlights some possible future directions of further research.

\section{RELATED WORK}

One of the first studies presented in student engagement is "Seven Principles for Good Practice in Undergraduate Education" [10] where, the seven principles are communication between student and faculty, the interaction between students, high expectations, active learning method, feedback for prompt, time consumed on task, and diverse respecting talents and learning ways.

Previous studies have dealt with student engagement in several aspects. In [11] represent student engagement as the number of logins and the average time to upload the assignment.

\subsection{Student Engagement: What It Means}

The concept of student engagement is one of the major factors contributing to desirable outcomes for the entire educational process [5]. The diversity of theoretical framework of engagement in previous studies has resulted in fragmented literature, as researchers tend to choose definition, model, and measurement from previous research without questioning the theoretical framework. This made it difficult to compare findings across previous studies and examine similarities and differences to build a review of engagement [12].

Therefore, engagement definition varies forms study to another, whereas in [2] Engagement term is defined as commitment or involvement. Engagement is the energy and effort that students put into their learning community and obtain feedback from faculty and staff, which can be observed through any number of behavioral, cognitive, or emotional/affective indicators across a single continuum [13] with lower levels of engagement indicating disengagement.

\subsection{Student Engagement Dimensions}

As mentioned above student engagement is multidimensional which is also varied in literature where researchers did not agree on these dimensions. In [14] consider student engagement has three dimensions which are behavioral engagement, emotional engagement, and cognitive engagement, this study considered as the almost one referenced, detailed, and comprehensive of student engagement models.

The definition of behavioral engagement from researcher can be the same as cognitive engagement activation from another researcher, so the measurement method differs from a study to another but the most common way to measure student engagement is through self-reports [12]. The study of [11] considered the number of posts on discussion forums, the number of content views, and the binary index of task completion measures of student engagement.

In [5] mentioned that there are many indicators of academic engagement, and provided that one of these indicators is how students use their time and emphasized that the only useful source of data is often the self-reports indicator. 


\section{MEASUREMENT, EVALUATION, AND RECOMMENDATIONS}

This article classified student engagement models of related work as in Fig 1 into earlier and newer models according to time. Firstly, divided earlier models into three types: contextual, interpersonal, and a hybrid model then give one model as an example for each class. In addition, the newer models are divided into behavioral and affective where, behavioral divided into academic, social, and cognitive models as in [4].

In [5] provided that when students choose activities within their competencies, they are more engaged. Rather, when given the opportunity, they may create the work

Furthermore, most researchers consider three student engagement dimensions, which are Behavioral engagement, Emotional engagement, and Cognitive engagement.

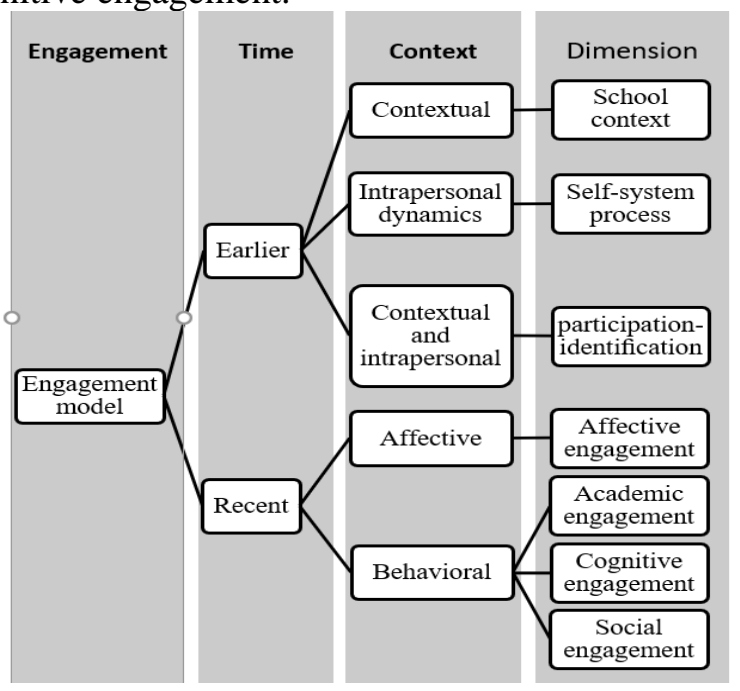

Figure 1: Classification of literature model' dimension.

\section{THE PROPOSED ENGAGEMENT FRAMEWORK}

There are diversified theoretical frameworks for student engagement in previous studies that led to fragmented models. Many researchers agreed that engagement is a multidimensional construct [12].

\subsection{Student Engagement Dimensions}

This article considers student engagement that consists of two main dimensions, the first being the behavioral dimension and the second is the emotional dimension as depicted in Fig 2. The behavioral dimension is divided into three sub-dimensions: academic, cognitive, and social.

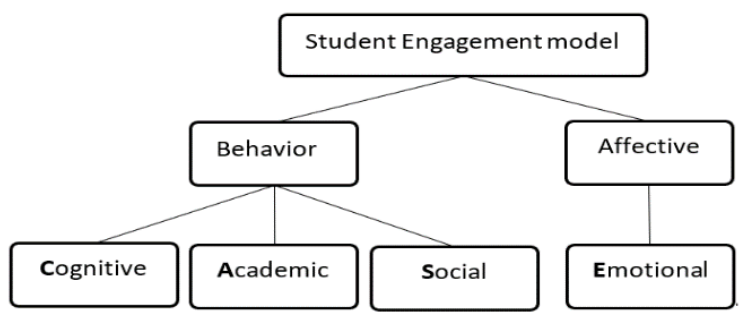

Figure 2: The Student engagement CASE model.

\subsubsection{The Behavioral Dimension}

Behavioral engagement is a concept that depend on the student's interactions related to task performance, including, e.g., engagement in academic and social activities, being active on time, completing tasks and 
homework. In addition, behavioral engagement also includes the ability of students to follow the rules and directives adhering to the standards of the classroom. It also includes the student's efforts to overcome educational challenges, and developing plans for an educational path in which he/she completes courses that increase his/her learning experiences related to his/her preferences. Avoiding unnecessary negative behaviors is another essential factor for achieving positive academic results [14], [2].

\section{Cognitive Engagement}

Cognitive engagement comes from the investment concept. Cognitive engagement is the student's effort to overcome educational challenges desiring to increase his/her learning experience through additional courses besides the minimum requirements for the current study. Of course, such courses are related to the student's preferences [14], [5].

Cognitive engagement includes higher-order thinking skills, willingness to do the maximum effort necessary to understand complex ideas and master difficult skills [4]. Noteworthy, many of the students seek to improve their competencies and are willing to take challenges to develop their skills and knowledge and to overcome educational failures by exerting excessive effort.

\section{Academic Engagement}

Academic engagement is recognized as the student's behavior related directly to the learning process, which may include completing assignments, attending, attentiveness, attempting, asking, answering, performing academic extracurricular activities, among many other formal and informal schooling requirements [15].

\section{Social Engagement}

Social engagement is defined as a combination of students' sense of belonging to the school, their sense of connection and acceptance with their colleagues and peers, good interaction with colleagues, and their general support for the concept of education [1]. Also, it is defined as the extent to which the student follows the written and unwritten rules of behavior in the classroom [4]. We can conclude that the student who feels bored, depressed, and even angry during class, is less involved in the educational process.

\subsubsection{The Affective Dimension (Emotional Engagement)}

Emotional engagement includes positive and negative reactions towards peers, academics, teachers, managers, and institutions, it influences the students' willingness to do the work. Emotional engagement is a combination of students' sense of belonging, a sense of competence, and motivation towards the concept of education [1].

\subsection{Student Engagement Indicators}

Indicators are the measures of the different dimensions of the engagement model. This section describes the different indicators to measure the engagement model dimensions. Student engagement is measured either directly by asking the learner to answer self-report, or indirectly through using various indicators or benchmarks such as active and collaborative learning; participation in challenging academic activities, etc. Students communicate with their faculty and participate in enriching educational experiences [1].

Indicators of activity engagement include counting-based measures and duration-based measures derived from the $\log$ data of the Learning Management System (LMS), where, counting-based is the number of times a student used the item, while duration-based represent the total time in hours that a student spent in an activity [15].

The framework of the National Survey of Student Engagement (NSSE) is a collection of information regarding effective educational practices collected through the participation of 1100 four-year colleges and universities and randomly selected more than one million students [5]. NSSE considers that there are five constructs linked to the learning outcomes. These five constructs are: level of the academic challenge, active and collaborative learning, student-faculty interaction, enriching educational experiences, and supportive campus environment.

This article uses two of these constructs as indicators, which are level of academic challenge, and active and collaborative learning. Besides, our model includes two other indicators, namely, student-learning experience environment interaction, and time spent on a task. These four indicators as described in what follows. 


\subsubsection{Level Of Academic Challenge}

The level of academic challenge is defined depending on seven principal theories [8] as having a potential of challenge in terms of the difficulty of the learning activities. It also refers to how hard students worked to complete their activities [16].

\subsubsection{Active and Collaborative Learning}

This construct is coming from the fact that "students learn more when they are intensely involved in their education" [5]. Therefore, active learning refers to students actively viewing, attempting, collaborative activities, and viewing and providing feedback about those activities of a course. Generally, active learning includes any teaching method that engages the student in the educational process in such a way to engage students in meaningful collaborative learning activities, and to enable students to think about what they are doing.

\subsubsection{Student-Learning Experience Environment Interaction}

Student-learning experience environment interaction is recognized as communication between the student and any educational environment that provides co-curricular activities inside or outside the classroom in which the student can obtain new educational experiences. Therefore, Co-curricular activity refers to additional activities that take place outside the regular curriculum, but which a student usually needs to complete their educational experience. Also sometimes known as extra-curricular activities. These activities may be required either in the context of the educational path or voluntary [1].

\subsubsection{Time Spent On A Task}

Time spent on a task is the time spent by a student to complete a particular learning activity [17], sometimes called the response time. This model is strongly reliable and sensitive to detect temporal changes in the student's participation level.

\section{MEASUREMENTS OF STUDENT ENGAGEMENT}

An LMS environment usually logs a tremendous amount of data about the different learning interactions. It provides data about every event performed by the student together with its timestamp. This includes all types of interactions, such as interaction with the instructor, interaction with their class and classmates, and interaction with the curriculum. Different aspects of learning interactions and their relation to the CASE model are depicted in Fig 3.

\subsection{Measurement Methods for CASE}

This article uses Moodle log (MDL-LOG) and experience Learning Record Store of Application Programming Interface (xAPI' LRS) as a source of aforementioned information about students' online behavior. MDL-LOG provides log data with the access timestamp, username, action, and information about each access, whereas, xAPI-LRS supports statements in the form of "Noun- verb- object" or "I did this," when the student interacts with an external learning environment. 


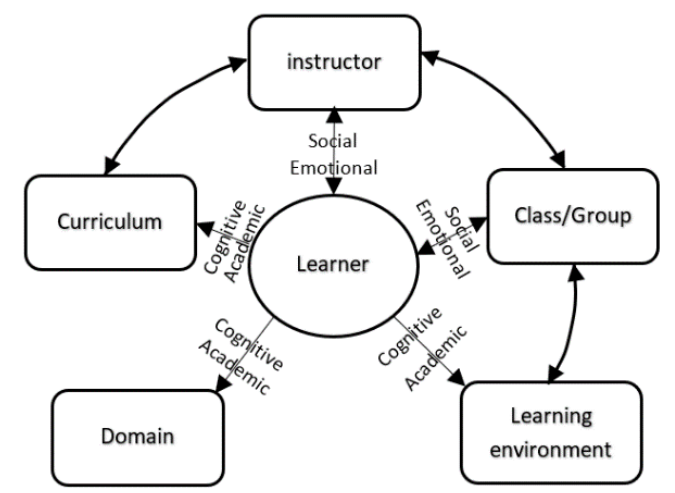

Figure 3: Learning interactions related to CASE model

The question now is, what do these actions or verbs express? How can this huge data be used and utilized? In light of the aforementioned definition of student engagement and its indicators, these events are considered as metrics of student interaction. Table 1 shows some learning interactions and their related metrics.

Table 1: Learning-Interactions and their related metrics.

\begin{tabular}{|c|c|}
\hline $\begin{array}{c}\text { Learning- } \\
\text { Interactions }\end{array}$ & metrics \\
\hline Learner -Instructor & $\begin{array}{c}\text { Viewing and providing feedback, } \\
\text { asking, chatting, attending, replying, } \\
\text { reviewing }\end{array}$ \\
\hline Learner-Activities & $\begin{array}{c}\text { Viewing, reading, writing, preparing, } \\
\text { working on their lessons, answering, } \\
\text { submitting, time spent, task completing }\end{array}$ \\
\hline Learner-Class/Group & $\begin{array}{c}\text { creating discussion, creating post, } \\
\text { replying, subscribing, commenting, } \\
\text { time spent, doing social actions }\end{array}$ \\
\hline Learner-Curriculum & $\begin{array}{c}\text { Creating resources, uploading } \\
\text { resources, Searching, planning, } \\
\text { continue studying, time spent }\end{array}$ \\
\hline
\end{tabular}

Most studies have adopted the measurement of engagement using the method of psychometric survey, which, unfortunately, cannot prove whether or not these answers accurately represent students' behaviors and perceptions. The direct reason of discrepancies is usually relayed to misinterpretations of the questionnaire. Psychometric indicators may be acceptable, but students have interpreted some of their elements to a different meaning.

In this article, we rely more on automatic collection of data in an objective manner rather than the subjective questionnaire method. Learning analytics provides more realistic, objective, and timely evident results as compared to the survey approach [18]. Our proposed measurement methods are based on MDL-LOG \& LRS include counting-based measures and duration-based measures. Table 2 summarizes the methods suggested for measuring each of the four dimensions of the CASE model. These measures are considered as a single continuum, where low levels indicate no engagement.

\subsection{Measurements According To The Coi Theory}

The CoI theory assumes that educational experience is a function of the interconnection of social presence, cognitive presence, teaching presence, and learning presence. 
Table 2: Measurement methods of CASE model.

\begin{tabular}{|c|c|}
\hline CASE model & Measurement method \\
\hline Cognitive & MDL-LOG \& xAPI-LRS \\
\hline Academic & MDL-LOG \& XAPI-LRS \\
\hline Social & Questionnaire \& MDL-LOG \& xAPI-LRS \\
\hline Emotional & Questionnaire \\
\hline
\end{tabular}

Cognitive presence is the extent of the participants' ability to build perceived knowledge through continuous interaction in any particular configuration of a community of inquiry [7]. Cognitive depth is the implementation of cognitive presence, as it is discussed in the following section.

Social presence is the degree of the sense-of-belonging, perception, and interaction of being connected by mediated information communication technology [19]. Social breadth is the implementation of social presence, as we will discuss in the following section.

Teaching presence is "designing, facilitating, and directing cognitive and social processes to achieve meaningful and personally meaningful learning outcomes [7]". All teachers should have the ability to ensure that students understand the content of the subject area with a deeper understanding. Through active and timely intervention, the teacher directs low engagements, accepts individual contributions, promotes suitable contributions, creates space for discussion, and generally facilitates various educational activities [7].

\section{LAST-CASE FRAMEWORK}

The proposed framework clarifies the link between educational interactions and the CASE model on the one hand and the LAST model on the other hand. The educational interactions are measured first through a dataset, using the counting-based measurement method and duration-based measurement method, then, in turn, the elements of each model can be measured.

We have named the proposed framework with LAST-CASE as a unique identifier. Fig 4 depicts LAST-CASE framework, where the links between the CASE model and the different learning interactions are shown on the right side, while the links between the LAST model and the learning interactions as shown on the left side. This indicates that the KPIs of both models - CASE and LAST models - are measures using the same metrics, the metrics of the Learning Interactions.

\section{LAST-CASE IMPLEMENTATION}

The proposed student engagement model uses both the cognitive depth and the social breadth as measurement basis, in addition to the counted-based, duration-based measures, and questionnaires. The counting-based method is applied to find the number of times the student did a certain action and hence, calculate the time spent to complete a task. Similarly, for all aspects, the value of all the dimensions of the CASE model. For example, to find the cognitive value, and using the weighted sum of the learner-activities, the learner-course/curriculum interaction can be calculated.

Table 3 summarizes the framework implementation of the LAST-CASE model, where, cognitive presence is implemented as a level of cognitive depth shown in Table 3 as rows. In the far left column, we divided the learning items into three clusters so that each one is given a different weight, and therefore the same event takes the weight of the cluster in which it occurred. 


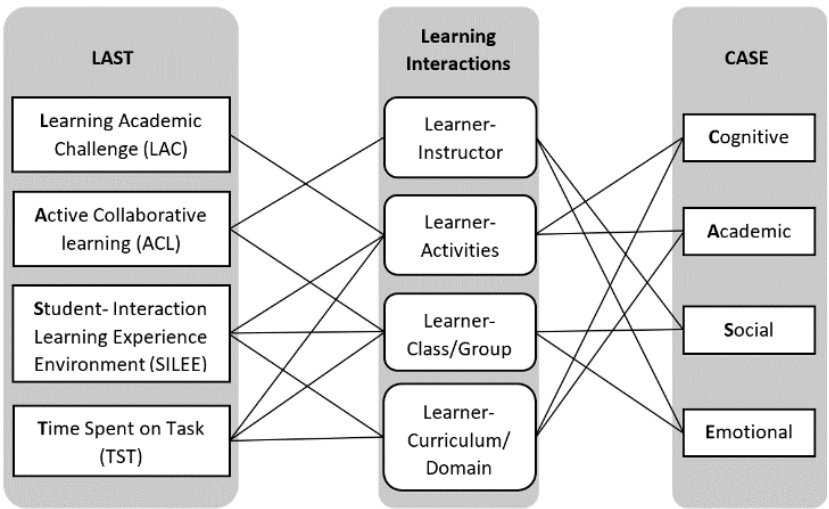

Figure 4: The proposed LAST-CASE student engagement framework.

The level of student engagement is the function of the type of activity presented to the student. The level expresses the extent to which the student demonstrates cognitive engagement in that activity.

The depth level ranges from level 0 to peak level 5, where the number 0 indicates that the learner has not even viewed the activity. In the proposed framework, we considered that students' viewing of activities does not have the same degree. We divided activities into three categories, each with a different weight depending on the importance level of each according to the defined objectives of the educational institution. The first category is the resources activities category, the second category is the duties activities, and the third category is the social communication activities. For instance, the weights can be set for a certain set up in such a way that the weight of viewing resources is less than viewing assignments, which in turn is less than viewing social activities.

Table 3: Levels of Cognitive depth with their learning items.

\begin{tabular}{|c|c|c|c|c|c|c|}
\hline Type & Learning Items & Level1 & Level2 & Level3 & Level4 & Level5 \\
\hline 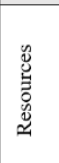 & $\begin{array}{c}\text { Course, Lesson, } \\
\text { Book, Glossary, } \\
\text { Wiki, SCORM, } \\
\text { Folder } \\
\text { other resources }\end{array}$ & $\begin{array}{l}\text { View } \\
\text { Click }\end{array}$ & $\begin{array}{l}\text { Read } \\
\text { Start } \\
\text { Play } \\
\text { Pause }\end{array}$ & $\begin{array}{c}\text { Download } \\
\text { Forward } \\
\text { Backward } \\
\text { End }\end{array}$ & $\begin{array}{c}\text { Searching, } \\
\text { Planning } \\
\text { Extra- } \\
\text { content, } \\
\text { creating }\end{array}$ & $\begin{array}{l}\text { Study extra- } \\
\text { content, } \\
\text { complete }\end{array}$ \\
\hline 总 & $\begin{array}{c}\text { Quiz, Assignment, } \\
\text { Exam, Question } \\
\text { bank, } \\
\text { Questionnaires } \\
\text { Self-assessments }\end{array}$ & $\begin{array}{l}\text { View } \\
\text { Click }\end{array}$ & $\begin{array}{l}\text { Attempt } \\
\text { answer } \\
\text { write }\end{array}$ & $\begin{array}{c}\text { Submit } \\
\text { View- } \\
\text { feedback }\end{array}$ & $\begin{array}{l}\text { Provide- } \\
\text { feedback } \\
\text { Solve- } \\
\text { challenge- } \\
\text { task }\end{array}$ & $\begin{array}{c}\text { Re-submit, } \\
\text { Review }\end{array}$ \\
\hline 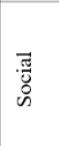 & $\begin{array}{c}\text { Forum, Discussion, } \\
\text { post, Chat-session, } \\
\text { Workshop, group- } \\
\text { work, other social } \\
\text { environments }\end{array}$ & $\begin{array}{l}\text { View } \\
\text { Click }\end{array}$ & $\begin{array}{c}\text { Subscribe } \\
\text { Create } \\
\text { Like/Share }\end{array}$ & $\begin{array}{c}\text { Post } \\
\text { Reply } \\
\text { Comment }\end{array}$ & $\begin{array}{l}\text { Provide- } \\
\text { feedback } \\
\text { Send- } \\
\text { message }\end{array}$ & $\begin{array}{l}\text { Re-submit, } \\
\text { Review }\end{array}$ \\
\hline
\end{tabular}

Some activities are not useful for the student engagement measurements, such as watching his/her score, etc. These activities are usually neglected.

The proposed framework implements social presence as "social breadth" by examining the breadth of opportunities for the participant to communicate with others. The amplitude level ranges from 0 to 5 , where the number 0 indicating that the learner did not interact with anyone. Level1 indicates that the learner did not interact with any other participant in this activity. Level2 indicates that the learner has interacted with at least one participant. Level 3 indicates that the learner interacted with many participants in this activity, where Level 4 indicate that the Learner Interacted with colleagues in a "barrage" of round-trip communications. While Level 5 is the learner, interacting with people outside the classroom.

As mentioned above, the proposed framework is based on learning analytics of LOG files by applying the countbased method and duration-based method. We obtained a raw dataset from Moodle [20]. It, then, was preprocessed to give about 1685 records ready to involve in the analytics process.

The mathematical representation of our framework is as follows: 


$$
E_{j}=\sum_{i=1}^{n} X_{i j} w_{l}
$$

Where, $E_{j}$ represents engagement $X_{i j}$ represents frequency of metric $i: i=1,2, \ldots . n$ related to learning interaction: $j=1,2,3,4, w_{l}$ represent the weight.

After we get the value of student engagement for each learning interaction, we can find the elements of the CASE model as follows:

$$
\begin{gathered}
E_{C}=\frac{E_{2}+E_{4}}{\sum_{j=1}^{4} E_{j}} \\
E_{A}=\frac{E_{2}+E_{4}}{\sum_{j=1}^{4} E_{j}} \\
E_{S}=\frac{E_{1}+E_{3}}{\sum_{j=1}^{4} E_{j}} \\
E_{E}=\frac{E_{1}+E_{3}}{\sum_{j=1}^{4} E_{j}}
\end{gathered}
$$

Where, $E_{C}, E_{A}, E_{S}, E_{E}$ are Cognitive, Academic, Social, Emotional engagement respectively.

Noteworthy, the differences can be shown through comparisons through three types: first, absolute comparisons, relative comparisons, and social comparisons. In the absolute comparisons, a fixed criterion is used as a reference of analysis for an individual, while in the relative comparisons, historical data for an individual's interactions are used as a reference to monitor his/her progress over time. Finally, the Social comparison uses a selected peer group or the class as the basis reference frame, i.e., the student's interaction is compared with the peers over a given period [21].

\section{CONCLUSION AND FUTURE WORK}

This article presented the proposed LAST-CASE student engagement framework to measure student engagement based on the CoI recommendations, MDL-LOG, and xAPI-LRS. This model measures the student engagement from different perspectives to draw a full picture of the impacts that engagements can affect the different aspects of a course objectives and outcomes, such as cognitive, social, academic, and emotional. The article also suggested the different measuring attributes demonstrating how to measure each of the LAST-CASE elements in terms of the different MDL-LOG fields.

The recommendations that could be offered by the presented model can be further improved if it considered the learning context of each individual student, e.g., student's background, learning style, goals, cultural background, etc. These individual differences will surely affect the student's engagement and hence affects the analysis and recommendations. Therefore, we plan to continue this research by further investigating how the context-aware student measurements can affect the engagement model and hence, their impact on course design to increase the student's engagement level.

The LAST-CASE model considered only online learning and on-line activities. The question is "can this model be affected in blended learning?" a question that we still need to investigate in our future research plans.

\section{ACKNOWLEDGMENT}

This research is partially supported by the Egyptian Information Technology Industry Development Authority (ITIDA) under ITAC project number CFP159 titled "EduEdges: An Adaptive e-Learning Platform". 


\section{REFERENCES}

[1] Mayadas, F., Miller, G., \& Sener, J., "Definitions of e-learning courses and programs," 2015. [Online]. [Accessed jan 2021].

[2] Hu, Y. L., Ching, G. S., \& Chao, P. C., "Taiwan student engagement model: Conceptual framework and overview of psychometric properties," International Journal of Research Studies in Education, vol. 1, no. 1, pp. 69-90, 2012.

[3] Henderson, M. Selwyn, N. and Aston, R., "What works and why? Student perceptions of 'useful' digital technology in university teaching and learning.," Studies in Higher Education, pp. 42-60, 2017.

[4] Finn, J. D., \& Zimmer, K. S. , "Student engagement: What is it? Why does it matter?," in In Handbook of research on student engagement, Boston, MA., Springer, 2012, pp. 97-131.

[5] G. D. Kuh, " The national survey of student engagement: Conceptual and empirical foundations," New directions for institutional research,, vol. 141, pp. 5-20, 2009.

[6] Beer, C., Clark, K., \& Jones, D. , "Indicators of engagement," Proceedings ascilite Sydney, pp. 75-85, 2010.

[7] Andrew Downes, et al, "Overview," The Advanced Distributed Learning (ADL) Initiative, [Online]. Available: https://xapi.com/overview/. [Accessed 21 jan 2021].

[8] Garrison, D. R., Anderson, T., \& Archer, W. , "Critical inquiry in a text-based environment: Computer conferencing in higher education," The internet and higher education, vol. 2, no. 2-3, pp. 87-105, 2000.

[9] B. Mayeku, "Enhancing personalization and learner engagement through context-aware recommendation in TEL," in In Proceedings of the 8th ACM Conference on Recommender systems, 2014.

[10] Chickering, A. W., \& Gamson, Z. F. , "Seven principles for good practice in undergraduate education," in AAHE bulletin, 1987.

[11] Moubayed, A., Injadat, M., Shami, A., \& Lutfiyya, H., "Student Engagement Level in an e-Learning Environment: Clustering Using K-means," American Journal of Distance Education, pp. 1-20, 2020.

[12] Fredricks, J. A., Filsecker, M., \& Lawson, M. A. , "Student engagement, context, and adjustment: Addressing definitional, measurement, and methodological issues.," Learning and Instruction, pp. 1-84, 2016.

[13] Bond, M., \& Bedenlier, S. , " Facilitating Student Engagement through Educational Technology: Towards a Conceptual Framework," Journal of Interactive Media in Education, 2019.

[14] Fredricks, J. A., Blumenfeld, P. C., \& Paris, A. H., "School engagement: Potential of the concept, state of the evidence," Review of educational research, vol. 74, no. 1, pp. 59-109, 2004.

[15] Willms, J. D., Friesen, S. \& Milton, P. , "What did you do in school today? Transforming classrooms through social, academic, and," Canadian Education Association (CEA), Toronto, 2009.

[16] Ö. Delialioğlu, "Student engagement in blended learning environments with lecture-based and problembased instructional approaches," Journal of Educational Technology \& Society, vol. 15, no. 3, pp. 310$322,2012$.

[17] E. Joseph, "Engagement tracing: using response times to model student disengagement," in Artificial intelligence in education: Supporting learning through intelligent and socially informed technology, 
Pittsburgh, PA., IOS press, 2005, pp. 88-95.

[18] Ma, J., Han, X., Yang, J., \& Cheng, J. , " Examining the necessary condition for engagement in an online learning environment based on learning analytics approach: The role of the instructor," The Internet and Higher Education, vol. 24, pp. 26-34, 2015.

[19] Gray, J. A., \& DiLoreto, M. , "The effects of student engagement, student satisfaction, and perceived learning in online learning environments," International Journal of Educational Leadership Preparation, 2016.

[20] Moodle' Authers, "1," Moodle.net, Aug 2016. [Online]. Available: https://research.moodle.net/158/. [Accessed 10 2020].

[21] Vytasek, J. M., Patzak, A., \& Winne, P. H., "Analytics for student engagement," in In Machine Learning Paradigms, 2020.

[22] Ballard, J., \& Butler, P. I., " Learner enhanced technology," Journal of Applied Research in Higher Education, 2016.

[23] Osguthorpe, R. T., \& Graham, C. R. , "Blended learning environments," Quarterly Review of Distance Education, vol. 4, no. 3, pp. 227-233, 2003.

[24] Wang F.H., "An exploration of online behaviour engagement and achievement in flipped classroom supported by learning management system," Computers \& Education , 2017.

[25] R. A. e. a. Silveira, "Learning objects recommendation system: issues and approaches for retrieving, indexing and recomend learning objects.," 2015.

[26] R. M. Raja Hussain, "Transforming to please: personalize learning environment and student engagement," in Improving University Teaching, Glasgow, Scotland, 2008.

[27] W. Peng, "Research on model of student engagement in online learning.," Eurasia Journal of Mathematics, Science and Technology Education,, pp. 13(7), 2869-2882, 2017.

[28] E. M, "1," 8 June 2016. [Online]. Available: http://www.differencebetween.net/language/wordslanguage/difference-between-inquiry-and-query/. [Accessed 12 july 2020].

[29] D. a. M. L. Jannach, " "Investigating personalized search in e-commerce."," in The Thirtieth International Flairs Conference., 2017.

[30] D. R. T. A. a. W. A. Garrison, ""Critical inquiry in a text-based environment: Computer conferencing in higher education."," The internet and higher education 2, no. 2-3, pp. 87-105, 1999.

[31] F. A. e. a. Dorça, "An approach for automatic and dynamic analysis of learning objects repositories through ontologies and data mining techniques for supporting personalized recommendation of content in adaptive and intelligent educational systems.," in IEEE 17th International Conference on Advanced Learning Technologies (ICALT)., 2017.

w. author, "1,

$29 \quad$ june $2020 . \quad$ [Online].

Available: https://en.wikipedia.org/wiki/Community_of_inquiry\#cite_note-1. [Accessed july 2020].

[33] admin, "1," [Online]. Available: https://coi.athabascau.ca/coi-model/description-cognitive-presence/. [Accessed 12 july 2020].

[34] Sangrà, A., Vlachopoulos, D., \& Cabrera, N. , "Building an inclusive definition of e-learning: An approach to the conceptual framework," International Review of Research in Open and Distributed 
Learning, vol. 13, no. 2, pp. 145-159, 2012.

[35] Garrison, D. Randy, and J. Ben Arbaugh, "'Researching the community of inquiry framework: Review, issues, and future directions."," The Internet and higher education, vol. 10, no. no. 3, pp. 157-172., (2007). 